\title{
Energy intake, expenditure and pattern of daily activity of Nigerian male students
}

\author{
BY A. H. COLE AND J. O. OGBE \\ Department of Human Nutrition, College of Medicine, University of Ibadan, \\ Ibadan, Nigeria
}

\section{(Received 9 February 1987 - Accepted 28 May 1987)}

\begin{abstract}
1. Twenty apparently healthy and normal Nigerian male students, resident at the University of Ibadan campus, were studied for seven consecutive days to assess their food energy intake and expenditure and pattern of their daily activities.

2. The mean age (years) of the group was 24.0 (SD 3.23, range 20-30), mean height (m) 1.71 (SD 0.06 , range $1 \cdot 61-1.84)$ and body-weight (kg) was $61 \cdot 1$ (SD 5.01, range $51 \cdot 0-69 \cdot 5$ ).

3. The food intake of each subject was obtained by direct weighing and its energy value determined using a ballistic bomb calorimeter. Patterns of daily activities were recorded and the energy costs of representative activities were determined by indirect calorimetry.

4. Activities mainly involved sitting, mean 580 (SD 167, range 394-732) min/d. Sleeping and standing activities took a mean of 445 (SD 112) and 115 (SD 75) min/d respectively. Personal domestic activities took a mean of 94 (SD 40) $\mathrm{min} / \mathrm{d}$.

5. The mean energy intake of the group was 11182 (SD 1970) $\mathrm{kJ} / \mathrm{d}$ or 183 (SD 32) $\mathrm{kJ} / \mathrm{kg}$ body-weight per $\mathrm{d}$. This value is lower than the $12.5 \mathrm{MJ} / \mathrm{d}$ recommended by the Food and Agriculture Organization (FAO)/World Health Organization (WHO) (1973) as the energy requirement for an adult man engaged in moderate activities, but it is higher than the FAO/WHO/United Nations University (UNU) (1985) recommended value of $10.8 \mathrm{MJ} / \mathrm{d}$ for a male office clerk (light activity). It is also lower than the recommended energy requirement of $11.6 \mathrm{MJ} / \mathrm{d}$ for a subsistence farmer (moderately active work) (FAO/WHO/UNU, 1985).

6. The mean energy expenditure of the male subjects was 9876 (SD 1064, range $7159-12259$ ) $\mathrm{kJ} / \mathrm{d}$ and was lower than mean intake.

7. The energy intake and expenditure values indicated that the groups participating in the present study were not physically very active. It is an indication that the Nigerian male students expended less but probably consumed more energy than required. It is suggested for health reasons and for mental fitness that the Nigerian male students might undertake more physical exercise.
\end{abstract}

Studies of energy intake, expenditure and cost of activities of Nigerian men, in particular male students, using indirect calorimetry, have not previously been conducted in Nigeria. There is no information on their habitual activities. The energy requirements of male students and those of other categories of the Nigerian population are not known, except those of Nigerian female students (Cole \& Ogungbe, 1987).

The First and Second Food and Agriculture Organization (FAO) Committees on Calorie Requirements (FAO, 1950, 1957) estimated energy expenditures of $13.4 \mathrm{MJ}(3200 \mathrm{kcal}) / \mathrm{d}$ for the reference man and $9.6 \mathrm{MJ}(2300 \mathrm{kcal}) / \mathrm{d}$ for the reference woman. These values have been reduced by the FAO/World Health Organization (WHO) (1973) to $12.5 \mathrm{MJ}$ $(3000 \mathrm{kcal}) / \mathrm{d}$ for the reference man and $9 \cdot 2 \mathrm{MJ}(2200 \mathrm{kcal}) / \mathrm{d}$ for the reference woman. Recently, the FAO/WHO/United Nations University (UNU) (1985) estimated the energy requirements for a male office clerk (light activity), 25 years of age, weighing $65 \mathrm{~kg}$, to be $10.8 \mathrm{MJ}(2580 \mathrm{kcal}) / \mathrm{d}$, that of a subsistence farmer (moderately active work), 25 years of age, weighing $58 \mathrm{~kg}$, to be $11.6 \mathrm{MJ}(2780 \mathrm{kcal}) / \mathrm{d}$ and that of a male engaged in heavy work, 35 years of age, weighing $65 \mathrm{~kg}$, to be $14.6 \mathrm{MJ}(3490 \mathrm{kcal}) / \mathrm{d}$.

Nicol (1949) was among the first in Nigeria to study the energy requirement of Nigerians. He reported a study on the nutrition of Nigerian peasant farmers with special reference to the effect of vitamin $A$ and riboflavin deficiency. He determined the energy and nutrient 
intakes of typical families, including both sexes, in Niger State of Nigeria, using tables of representative nutrient values from Nicholls (1945) and Platt (1945). Nicol (1956a) also studied the nutrition of Nigerian children, with particular reference to their energy requirements. The children studied were aged $4-6$ and $10-12$ years. However, he did not determine the energy cost of activities. Food composition tables of the FAO (Chatfield, 1949 , 1954) were used to obtain the nutrient contents of the diet. When these tables were insufficient, United States Department of Agriculture (Leung et al. 1952) and United Kingdom Medical Research Council (Platt, 1945) tables were used. Since the nutrient composition of several foodstuffs commonly used in Nigeria was not included in any of these tables, many of the foods were sent to the Government Chemist in London for analysis. Nicol (1956b) investigated further the nutrition of Nigerian children, with particular reference to their ascorbic acid requirements. Between 1954 and 1957 Nicol (1959) carried out other studies on the energy requirements of Nigerian peasant farmers in various parts of the country. The method adopted for measuring food intake was individual inventory. FAO tables (Chatfield, 1953, 1954) were used to obtain energy values and nutrient compositions of the diets.

Fox (1953) calculated the daily energy expenditure of Gambian farmers for periods of up to 1 month. The results expressed per head do not indicate the energy output of men and women separately. Philips (1954) reported a study on the metabolic cost of common West African agricultural activities. He used seven Nigerians employed by the Colonial Medical Research Committee's Laboratory for Hot Climate Physiology, Oshodi, near Lagos. Subjects for the study were five daily-paid labourers, a messenger and a driver. The method used for measuring oxygen intake was the indirect open method, using a Douglas bag of 500 litres capacity and a mouth piece with a two-way, low-resistance-rubber respiratory valve. Ancey (1974), quoted by Bleiberg et al. (1980), reported a study in which the duration of all tasks of a large group of female farmers from different villages was recorded by recall on a 1-year basis.

In Upper Volta, Bleiberg et al. (1980) studied the duration of activities and energy expenditure of female farmers in dry and rainy reasons using indirect calorimetry for the determination of the energy cost of activities. Brun et al. (1981) investigated the energy expenditure of male farmers in dry and rainy seasons in Upper Volta using indirect calorimetry (for approximately $10 \mathrm{~min}$ ) by means of a Kofranyi-Michaelis respirometer. The energy costs of various activities were computed from the equation given by Durnin \& Passmore (1967) and based on Weir's (1949) formula. Also Brun et al. (1979) studied the energy expenditure of Iranian agricultural workers using indirect calorimetry. Viteri et al. (1971) reported a study on the energy costs of agricultural activities of eighteen Guatemalan workers employed on the farm, using respirometer and energy-balance techniques.

Schutz et al. (1980) investigated the energy expenditure and food intake of lactating women in Guatemala using heart rate to monitor the energy expenditure. Norgan et al. (1974) reported the results of a study of energy expenditures of 204 New Guinean adults. Ferro-Luzzi et al. (1975) studied the food intake, its relation to body-weight and age, and its apparent nutritional adequacy for 482 New Guinean children, aged 1-18 years living in two contrasting environments near the coast (Kaul) and in a highland region (Lufa). The method used for measuring food intake was by weighed individual inventory over 5-7 consecutive days.

Cole et al. (1977) reported findings on the energy utilization of obese and normal-weight clinical patients with different physical activities and Klein et al. (1984) did a study on the calorimetric validation of the doubly-labelled water method for determination of energy expenditure in man. 
The present study was carried out to determine the daily energy intake and expenditure of male adult students and to compare the results with values given by the FAO/WHO/ UNU (1985).

The method used for assessing intake was the individual inventory method and the energy value of food was determined using a ballistic bomb calorimeter. Energy expenditure was measured according to the method previously described by Cole (1976) and similarly by Durnin \& Brockway (1959) and Davidson et al. (1975).

\section{MATERIALS AND METHODS}

\section{Subjects}

Twenty male students were selected at random from different halls of residence in the University of Ibadan. They were from different departments and faculties of the University.

Before the commencement of the study the purposes and objectives were explained in detail to the subjects and they agreed to participate. Specific instructions were given to them not to alter their habits, routine activities and the pattern of food intakes.

All the subjects were engaged in similar activities: walking to lecture halls, laboratories and cafeteria; sitting down listening to lectures, jotting down notes and having seminar discussions or reading in the library or hall of residence, sitting down listening to music and watching television or having friendly discussion, standing or sitting while performing some personal and domestic activities in the hall of residence. A few of the subjects from the science faculty performed laboratory work as part of their normal routine.

\section{Food intake}

The subjects obtained their meals (breakfast, lunch and supper) from the main cafeteria of the University of Ibadan on each of the seven consecutive days; very few prepared their own food in the hall of residence. The type of foodstuff and their preparation have been previously described by Cole \& Ogungbe (1987).

\section{Measurement of food intake}

Before the commencement of the study, the purpose and methods of the investigation were fully explained to each male student in his hall of residence. The subjects were taught how to measure and weigh their food accurately. A Salter balance calibrated up to $10 \mathrm{~kg}$ in $50 \mathrm{~g}$ divisions was supplied to each of the students. Beakers were provided for measuring fluids, and plastic containers for easy weighing of such foods as jam, sugar and butter.

The total daily food intake of each subject was measured for seven consecutive days by the inventory method described by Garry et al. (1959) and Durnin et al. (1957), each item of food being separately weighed and recorded. Plate waste was weighed and the amount subtracted from the original portion weight of food. The investigators and two male field officers from the Human Nutrition Department, College of Medicine, University of Ibadan, visited the hall of residence and the cafeteria once daily, usually at meal times, to ensure accurate recording of food intake and to help with any difficulties.

Apart from food intake in the cafeteria or hall of residence the weights of snacks (which were usually meat pie, biscuits, sausage rolls, carbonated drinks) bought outside were obtained by buying and weighing similar quantities. Samples of all foodstuffs, including snacks, consumed by individual subjects were collected in labelled plastic containers for analysis. The determination of the moisture content of each sample was carried out and the value obtained was used to calculate the dry weight of each food item. The samples were dried in a vacuum oven and homogenized. The heat of combustion was determined using 
a ballistic bomb calorimeter (CB-370; Gallenkamp and Co. Ltd, London). The values obtained were used in calculating the energy intake of the subjects.

For snacks such as carbonated drinks, and for jam, butter, sugar and milk, standard values for energy contents were obtained from food composition tables (Haenel, 1979).

\section{Recording of activities}

Diary sheets were completed by each subject to obtain a minute-by-minute record of all daily activities (from getting out of bed in the morning to returning to bed at night). This was done throughout the seven consecutive days of the study. A preliminary study was carried out before the main study to establish the ability of each subject to keep detailed activity records. The information supplied from the recording was classified under the following headings: lying down in bed (resting); sitting down listening to lectures or taking notes; eating; listening to the radio; washing clothes; polishing shoes; cleaning the room or fetching water, etc.; walking and climbing stairs at fast, normal or slow pace. The sum of the expenditures in these activities was obtained for the $7 \mathrm{~d}$ of the study; details of the method have been described previously (Cole, 1976).

\section{Measurement of energy expenditure}

Indirect calorimetry was used to determine the energy cost of activities which were grouped as follows: sitting, standing, walking, lying down awake, climbing stairs, personal domestic necessities and sleeping. The energy cost was determined on five to ten selected male students for a period of 10-15 min. Daily energy expenditure was obtained by multiplying the total time-period spent on each activity by its energy cost.

The respiration-gasmeter of the Max-Planck Institute for Work Physiology (Dortmund), developed in Germany, modified by Müller \& Franz (1952) and manufactured by Gesellschaft für Gerätebau GmbH, KG 46 Dortmund, Westfalendamm 267-273, combined with face masks, was used to measure the volume of expired air $\left(\dot{V}_{E}\right)$. The respirometer was calibrated as described by Cole (1976). The face masks were available in three different sizes. They were manufactured by Volkseigener Betrieb Kombinat Medizin und Labor Technik, Leipzig. To suit our physiological purpose, the face masks were modified in the workshop of Zentral-Institut für Ernährung der Akademie der Wissenschaften der DDR, Potsdam-Rehbrücke.

The subject breathed through a face mask via a corrugated tube to the respirometer and from thence to an inflatable rubber bag which was placed inside a plastic sack which was filled with expired air to prevent changes in the gas content of the bladder (Rahaman \& Durnin, 1964) before analysis.

$\dot{V}_{E}$ and temperature (using the thermometer in the respirometer) of the expired air were recorded. Air pressure was measured using a barometer. The measured gas volume was corrected to standard temperature and pressure and the volume of expired air was derived from the expired volume and the gas concentrations. The oxygen and carbon dioxide concentrations of the mixed expired gas sampled by the inflatable bag through the respirometer were measured using a paramagnetic $\mathrm{O}_{2}$ analyser (Medical Analyser OM-11; Beckman) and a thermoconductive $\mathrm{CO}_{2}$ analyser (Medical Analyser LB-2; Beckman). Both analysers were calibrated regularly with a certified gas mixture of $\mathrm{O}_{2}, \mathrm{CO}_{2}$ and nitrogen (16:4:80, by vol.).

The protocol of the present study was approved by the Ethical Committee of the College of Medicine, University of Ibadan. 
Table 1. Mean daily energy intakes of twenty male students of University of Ibadan, Nigeria

\begin{tabular}{lccc}
\hline \hline Subject & $\begin{array}{c}\text { Eody-wt } \\
(\mathrm{kg})\end{array}$ & $\begin{array}{c}\text { Energy } \\
\text { intake } \\
(\mathrm{kJ} / \mathrm{d})\end{array}$ & $\begin{array}{c}\text { Energy } \\
\text { intake } \\
(\mathrm{kJ} / \mathrm{kg} \text { body-wt })\end{array}$ \\
\hline O. K. & $65 \cdot 5$ & 13576 & 207 \\
O. O. A. & $60 \cdot 5$ & 10784 & 178 \\
O. O. & $69 \cdot 5$ & 16113 & 232 \\
A. S. & $59 \cdot 6$ & 8285 & 139 \\
B. D. C. & $59 \cdot 0$ & 12297 & 208 \\
A. K. F. & $65 \cdot 0$ & 12008 & 185 \\
T. K. & $53 \cdot 0$ & 11713 & 221 \\
C. F. & $58 \cdot 0$ & 8736 & 151 \\
S. J. & $62 \cdot 5$ & 10289 & 165 \\
C. C. O. & $51 \cdot 0$ & 13143 & 258 \\
A. F. N. & $58 \cdot 5$ & 11252 & 192 \\
A. T. & $61 \cdot 0$ & 11972 & 196 \\
A. R. & $63 \cdot 0$ & 10846 & 172 \\
V. E. & $65 \cdot 0$ & 12535 & 193 \\
B. A. & $68 \cdot 0$ & 10744 & 158 \\
O. J. & $57 \cdot 5$ & 10722 & 187 \\
O. D. & $66 \cdot 0$ & 8036 & 122 \\
E. O. & $60 \cdot 6$ & 10831 & 179 \\
A. A. D. & $57 \cdot 5$ & 11601 & 202 \\
U. P. E. & $58 \cdot 5$ & 8161 & 140 \\
Mean & $61 \cdot 1$ & 11182 & 183 \\
SD & $5 \cdot 01$ & 1970 & 32 \\
\hline \hline
\end{tabular}

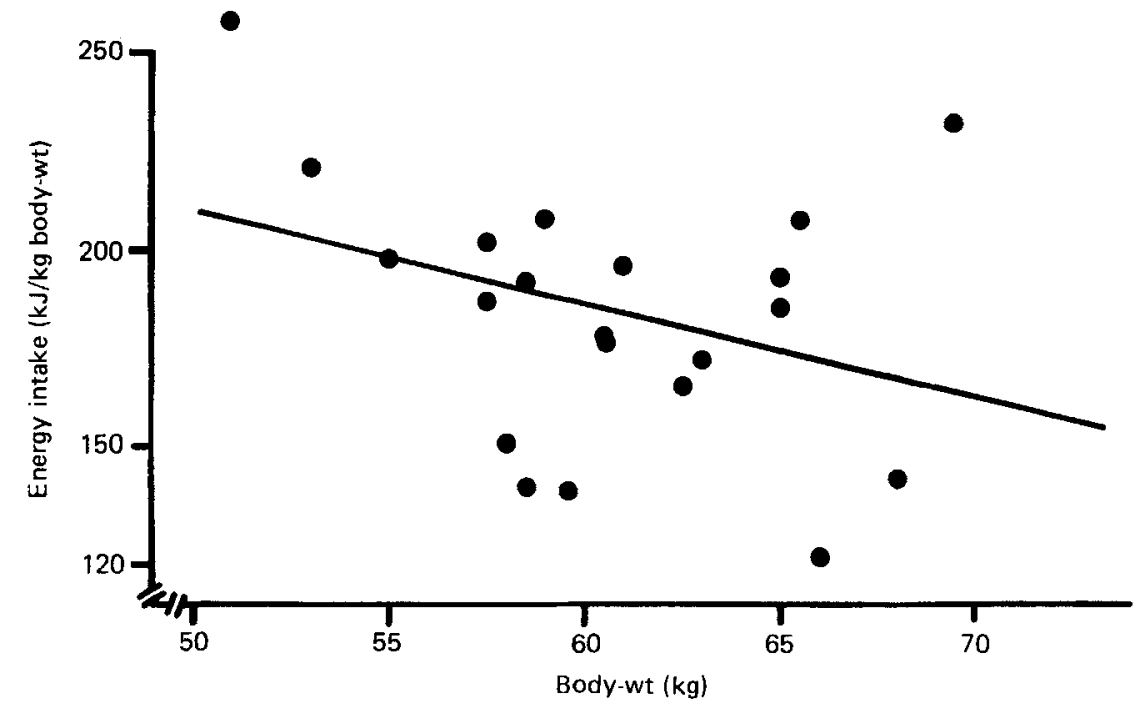

Fig. 1. Scatter diagram of the relation between energy intake $(\mathrm{kJ} / \mathrm{kg}$ body-weight) and body-weight $(\mathrm{kg})$ $(r-0.33, P>0.05)$.

RESULTS

The mean age of the twenty male students was 24 (SD 3.23) years, mean body-weight $61 \cdot 1$ (SD 5.01 ) $\mathrm{kg}$ and mean height 1.71 (SD 0.06 ) $\mathrm{m}$. The youngest subject was 20 years old with a body-weight of $57.5 \mathrm{~kg}$ and height of $1.70 \mathrm{~m}$. The oldest was 30 years old, weighing $59 \mathrm{~kg}$ and $1.78 \mathrm{~m}$ tall. 
Table 2. The mean daily energy balance $(k J)$ of twenty male students of the University of Ibadan, Nigeria

\begin{tabular}{lrrr}
\hline \hline Subject & $\begin{array}{r}\text { Energy } \\
\text { intake }\end{array}$ & $\begin{array}{r}\text { Energy } \\
\text { expenditure }\end{array}$ & $\begin{array}{r}\text { Energy } \\
\text { balance }\end{array}$ \\
\hline O. K. & 13576 & 10606 & 2970 \\
O. O. A. & 10784 & 9661 & 1123 \\
O. O. & 16113 & 8807 & 7306 \\
A. S. & 8285 & 10016 & -1731 \\
B. D. O. & 12297 & 9766 & 2531 \\
A. K. F. & 12008 & 11004 & 1004 \\
A. K. & 11713 & 7159 & 4554 \\
C. F. & 8736 & 9460 & -724 \\
S. J. & 10289 & 11523 & -1234 \\
C. C. O. & 13143 & 9460 & 3683 \\
A. F. N. & 11252 & 10305 & 947 \\
A. T. & 11972 & 8866 & 3106 \\
A. R. & 10846 & 9385 & 1461 \\
V. E. & 12535 & 10489 & 2046 \\
B. A. & 10744 & 9665 & 1079 \\
O. J. & 10722 & 9531 & 1191 \\
O. D. & 8036 & 12259 & -4223 \\
E. O. & 10831 & 10142 & 689 \\
A. A. D. & 11601 & 10058 & 1543 \\
U. P. E. & 8161 & 9351 & -1190 \\
\hline \hline
\end{tabular}

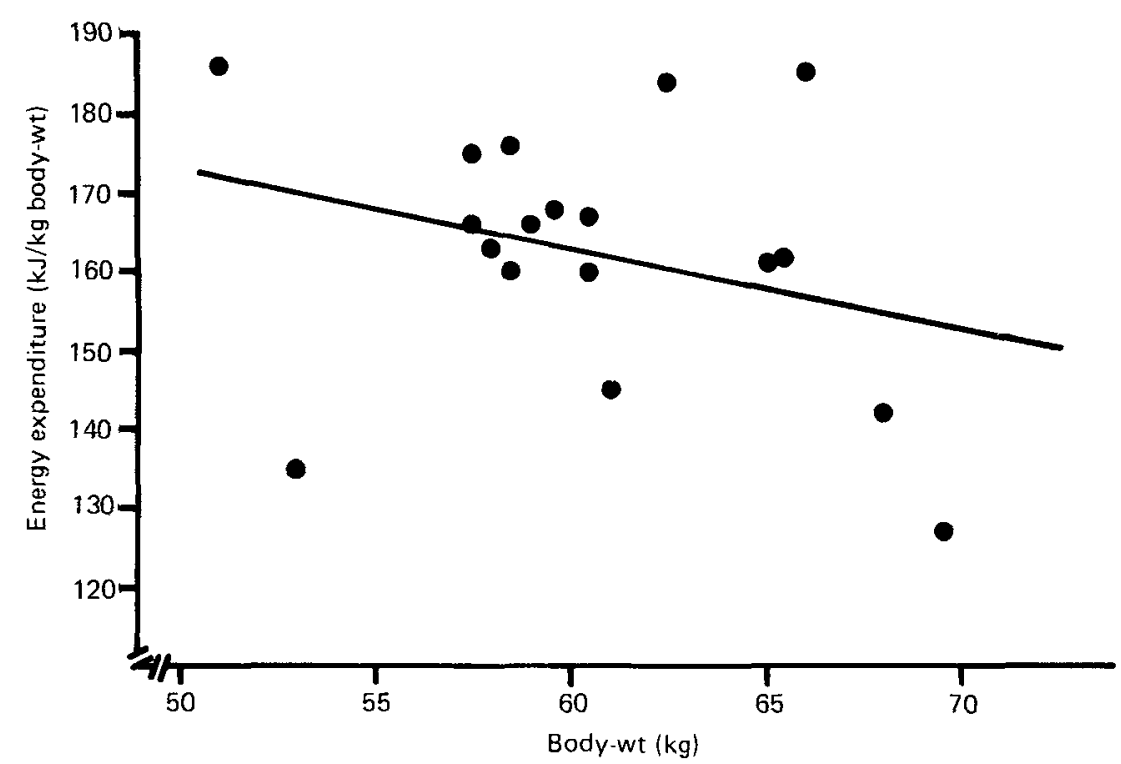

Fig. 2. Scatter diagram of the relation between energy expenditure (kJ/kg body-weight) and body-weight (kg) $(r-0.30, P>0.5)$.

\section{Energy intake}

There were variations in the energy intake of the individual students (Table 1). The mean energy intake of the students for $7 \mathrm{~d}$ was 11182 (SD 1970) $\mathrm{kJ} / \mathrm{d}$ or 183 (SD 32) $\mathrm{kJ} / \mathrm{kg}$ bodyweight. The highest energy intake was by subject 0.0 . $(16113 \mathrm{~kJ} / \mathrm{d}$ or $232 \mathrm{~kJ} / \mathrm{kg}$ bodyweight). Subject O.D. had the lowest daily energy intake consuming $8036 \mathrm{~kJ} / \mathrm{d}$ or $122 \mathrm{~kJ} / \mathrm{kg}$ body-weight. 
Table 3. Average period of time (min) spent on various activities by twenty male students of the University of Ibadan, Nigeria

\begin{tabular}{|c|c|c|c|}
\hline \multirow[b]{2}{*}{ Activity } & \multicolumn{2}{|c|}{ Time-period (min) } & \multirow{2}{*}{$\begin{array}{l}\text { Percentage } \\
\text { of } 24 \mathrm{~h} \\
\text { period }\end{array}$} \\
\hline & Mean & SD & \\
\hline Sitting & 580 & 167 & 40 \\
\hline Sleeping & 445 & 112 & 31 \\
\hline Standing & 115 & 75 & 8 \\
\hline Personal necessities & 94 & 40 & 7 \\
\hline Walking at normal pace & 83 & 32 & 6 \\
\hline Lying down in bed awake & 49 & 29 & 3 \\
\hline Climbing stairs & 32 & 36 & 2 \\
\hline
\end{tabular}

Table 4. Energy expenditure for various activities of male students of University of Ibadan, Nigeria

(Mean values and standard deviations)

\begin{tabular}{lccc}
\hline & No. of \\
Activity & \multicolumn{2}{c}{ Energy cost $(\mathrm{kJ} / \mathrm{min})$} \\
\cline { 3 - 4 } & \multicolumn{1}{c}{ subjects } & Mean & SD \\
Sitting & 10 & 5.55 & $2 \cdot 11$ \\
Walking at normal pace & 12 & 13.41 & 6.20 \\
Personal necessities & 7 & 11.51 & 3.90 \\
Climbing stairs & 5 & 23.20 & 6.51 \\
Lying down in bed awake & 6 & 4.73 & 0.40 \\
Standing & 7 & 11.51 & 3.90 \\
\hline
\end{tabular}

Effect of age and body-weight on energy intake

There was no significant relation between age and total energy intake $(r-0 \cdot 110, P>0 \cdot 05)$. There was also no significant relation between age and energy intake (Fig. 1) expressed as $\mathrm{kJ} / \mathrm{kg}$ body-weight $(r-0.33, P>0.05)$.

\section{Energy expenditure}

The results showed that fifteen of the twenty students had lower energy expenditures than energy intakes (Table 2). The mean expenditure was 9876 (SD 1064) kJ/d while the mean energy intake (Table 1) was 11182 (SD 1970) kJ/d. There was no significant relation between energy intakes and expenditures of the students $(r-0.28, P>0.05)$. For one student the mean energy intake was 8736 (SD 2512) kJ/d or 151 (SD 43) kJ/kg and the expenditure $9460 \mathrm{~kJ} / \mathrm{d}$ or $163 \mathrm{~kJ} / \mathrm{kg}$, while another subject had a higher expenditure $(11523 \mathrm{~kJ} / \mathrm{d}$ or $184 \mathrm{~kJ} / \mathrm{kg})$ and a lower energy intake $(10289 \mathrm{~kJ} / \mathrm{d}$ or $165 \mathrm{~kJ} / \mathrm{kg})$. Table 2 shows the mean daily energy balance of our male subjects over $7 \mathrm{~d}$. There was a significant relation between body-weight and energy expenditure expressed on a $\mathrm{kJ} / \mathrm{d}$ basis $(r 0.43$, $P<0.05$ ). However, when expressed on a $\mathrm{kJ} / \mathrm{kg}$ body-weight basis (Fig. 2) energy expenditure and body-weight were not correlated and the relation was not significant $(r-0.30, P>0.05)$.

\section{Activity}

Table 3 shows the mean periods of time spent on various activities. Sitting activities involved a mean of $580 \mathrm{~min} / \mathrm{d}$ ( $40 \%$ of the $24 \mathrm{~h}$ period), sleeping activities $445 \mathrm{~min} / \mathrm{d}$ ( $31 \%$ of the $24 \mathrm{~h}$ period), personal necessities $94 \mathrm{~min} / \mathrm{d}$ ( $7 \%$ of the $24 \mathrm{~h}$ period), walking 
activities $83 \mathrm{~min} / \mathrm{d}(6 \%$ of the $24 \mathrm{~h}$ period) while climbing stairs involved the least time ( $32 \mathrm{~min} / \mathrm{d}$ or $2 \%$ of the $24 \mathrm{~h}$ period). The total time spent by individuals on each activity varied. Student U.P.E. spent $697 \mathrm{~min} / \mathrm{d}(48 \%$ of the $24 \mathrm{~h}$ period) on sitting activities, also spending $578 \mathrm{~min} / \mathrm{d}(40 \%$ of the $24 \mathrm{~h}$ period) on standing activities. Subject A.S. spent $731 \mathrm{~min} / \mathrm{d}$ on sitting activities (51\% of the $24 \mathrm{~h}$ period) and $419 \mathrm{~min} / \mathrm{d}$ sleeping $(29 \%$ of the $24 \mathrm{~h}$ period). The energy cost of each of the eight activities was determined on five to ten selected male students. The results are presented in Table 4.

\section{DISCUSSION}

The present study shows substantial variations in the individual mean daily energy intake and particularly energy expenditure. There was also an apparently high energy intake but very low energy expenditure in some individual subjects. Bleiberg (1979) reported low energy intakes among some of the male farmers and most of the female farmers in Upper Volta; they consumed less than 6.27 MJ (1500 kcal)/d. However, Bleiberg (1979) obtained these values by using theoretical coefficients from groups of subjects of the same sex, eating from a common plate. These findings cannot be challenged or substantiated until similar studies are carried out in Nigeria.

A recent report (FAO/WHO/UNU, 1985) estimates the energy requirement of a male office clerk (light activity) to be $10.8 \mathrm{MJ}(2580 \mathrm{kcal}) / \mathrm{d}$. This value is higher than the mean value obtained in the present study (9876 (SD 1064) kJ (2360 (SD 254) kcal)/d). FAO/ WHO/UNU (1985) also estimated the mean daily energy requirement of a subsistence farmer (moderately active work) to be $11.6 \mathrm{MJ}(2780 \mathrm{kcal}) / \mathrm{d}$ which is also higher than the mean intake for our male subjects. Furthermore FAO/WHO/UNU (1985) also estimated the mean energy requirement of a male engaged in heavy work to be $14.6 \mathrm{MJ}$ $(3490 \mathrm{kcal}) / \mathrm{d}$ which is relatively higher than the mean energy intake of our male students. Earlier values such as those reported by the First and Second FAO Committees on Calorie Requirements (FAO, 1950, 1957) estimated energy expenditure to be $13.4 \mathrm{MJ}$ (3200 kcal)/d for a reference man. The estimate was later reduced by FAO/WHO (1973) to $12.5 \mathrm{MJ}(3000 \mathrm{kcal}) / \mathrm{d}$ for a reference man.

\section{Energy intake}

The food intake of the male students was characterized by bulky staple foods (roots and tubers) with some protein (fish, meat) and vegetable oils (palm oil, etc.). Few snacks were consumed in between the three meals, as reported for their female counterparts (Cole \& Ogungbe, 1987). During the $7 \mathrm{~d}$ study, the pattern of food intake did not differ in terms of food type (contents) or frequency of intake. The observed food habit was rather monotonous and only slight variations in energy intake were observed. The energy intakes obtained from the present study differed from those of a study in Khartoum and Cambridge (McCance et al. 1971). In this study, McCance et al. (1971) studied nine Sudanese male students in both Cambridge and Khartoum. The mean energy intakes in Cambridge and Khartoum were 13569 and $12435 \mathrm{~kJ}$ (3243 and $2972 \mathrm{kcal}) / \mathrm{d}$ respectively, which are higher than the mean intake of $11182 \mathrm{~kJ}(2673 \mathrm{kcal}) / \mathrm{d}$ obtained for male Nigerian University students (present study). However, the number of students studied by McCance et al. (1971) was small. Norgan et al. (1974) studied the New Guinean men from $\mathrm{Kaul}$ and Lufa and reported a mean energy intake of $8912 \mathrm{~kJ}(2130 \mathrm{kcal}) / \mathrm{d}$ for nineteen Kaul men, which is lower than the mean energy intake observed for Nigerian students. For the Lufa men, Norgan et al. (1974) recorded a mean energy intake of $10368 \mathrm{~kJ}$ $(2478 \mathrm{kcal}) / \mathrm{d}$ for twenty-eight Lufa male subjects; this is also lower than the mean energy intake of our subjects. 


\section{Energy expenditure}

The mean energy expenditure in the present study was lower than the mean energy intake. In the study of I. S. Dema (quoted in Brun et al. 1981), the mean energy expenditure was $13054 \mathrm{~kJ}(3120 \mathrm{kcal}) / \mathrm{d}$ for Nigerian men which is significantly higher than the mean value obtained in the present study $(9876 \mathrm{~kJ})(2360 \mathrm{kcal}) / \mathrm{d}$ and also higher than the mean energy expenditure of $11330 \mathrm{~kJ}(2708 \mathrm{kcal}) / \mathrm{d}$ for the eight Sudanese male students in Khartoum (McCance et al. 1971). As there has been no previous assessment of the energy expenditure of Nigerian or West African male students, it is not possible to compare the present findings with the results from similar surveys. However, for the purpose of comparison we have used some information on energy expenditure of men and male farmers in The Gambia, Upper Volta, New Guinea and Guatemala. The values recorded in the present study are slightly lower than those reported by others (FAO/WHO, 1973; Brun et al. 1981; FAO/WHO/ UNU, 1985). The energy expenditure of the subjects in the present study was $5.55 \mathrm{~kJ}$ $(1.33 \mathrm{kcal}) / \mathrm{min}, 4.73 \mathrm{~kJ}(1.13 \mathrm{kcal}) / \mathrm{min}$ and $13.39 \mathrm{~kJ}(3.2 \mathrm{kcal}) / \mathrm{min}$ for sitting, lying down and walking activities respectively. Comparative values based on FAO/WHO/UNU (1985) estimates are $5.02 \mathrm{~kJ}(1.2 \mathrm{kcal}) / \mathrm{min}, 5.02 \mathrm{~kJ}(1.2 \mathrm{kcal}) / \mathrm{min}$ and $13.39 \mathrm{~kJ}(3.2 \mathrm{kcal}) / \mathrm{min}$ respectively. However, the value recorded for walking activities in the present study of $13.39 \mathrm{~kJ}(3.2 \mathrm{kcal}) / \mathrm{min}$ is higher than that recorded for similar activities by Bleiberg et al. (1980) of $12.3 \mathrm{~kJ}(2.9 \mathrm{kcal})$. The values obtained by Brun et al. (1981) for Upper Volta male farmers and Norgan et al. (1974) for New Guinean men for sitting, lying down and standing activities are quite similar to FAO/WHO/UNU (1985) values but slightly higher than the values obtained in the present study. However, the recorded energy intakes and expenditures of individual subjects in the present study are similar to the values reported by other authors (de Guzman, 1984; Zhi-Chien, 1984). The observation that most of our male students consumed more and expended less energy during the study (seven consecutive days) may not reflect their regular pattern of life.

\section{Activity}

It was observed that the male students spent the greater proportion of their time on activities involving sitting or sleeping. This observation is similar to that reported for female students (Cole \& Ogungbe, 1987). On some occasions the male students sat down either reading, eating, watching television or chatting with friends. Although these activities are characteristic of students, it might also be expected that the students should engage themselves in recreational activities involving forms of physical exercise which are conducive to cardiovascular, mental and physical fitness.

Age did not influence either energy intake or expenditure in the present study. Despite the slight differences in age and body-weight of the male subjects, fifteen of twenty students had a higher energy intake than expenditure.

The present study is the first study in Nigeria on energy intake and expenditure of Nigerian male students based on indirect calorimetry. Although the present study may not be truly representative of the energy intakes and expenditures of male students in Nigeria, it is suggested that the study be extended to other groups in Nigeria in order to establish appropriate dietary and energy allowances.

The authors are very grateful for partial financial assistance from the Nestle Nutrition Research Grant Programme Committee, London, under the chairmanship of Professor J. C. Waterlow, and the Postgraduate Institute of Medical Research and Training, College of Medicine, University of Ibadan, Ibadan, Nigeria. Appreciation is also extended to Mrs 
Cornelia E. Cole for her technical assistance and to the male students of the University of Ibadan who participated in the study.

\section{REFERENCES}

Ancey, G. (1974). Facteurs et Systèmes de Production dans la Société Mossi d'Aujourd' hui. Migration-Travail-Terre et Capital. O.R.S.T.O.M. Centre d'Ouagadougou.

Bleiberg, F. (1979), Etat nutritionnel, consommation alimentaire et dépense énergétique du paysan Mossi. Thèse de 2ème cycle, Université Pierre et Marie Curie, Paris.

Bleiberg, F. M., Brun, T. A. \& Goibhman, S. (1980). British Journal of Nutrition 43, 71-82.

Brun, T. A., Bleiberg, F. \& Goibhman, S. (1981). British Journal of Nutrition 45, 67-75.

Brun, T. A., Geissler, C. A., Mirbagheri, I., Mormozdiary, H., Bastani, J. \& Hedayat, H. (1979). American Journal of Clinical Nutrition 32, $2154-2161$.

Chatfield, C. (1949). Food and Agriculture Organization Nutrition Study no. 3. Rome: FAO.

Chatfield, C. (1953). Food and Agriculture Organization Nutrition Study no. 3. 2nd ed. Rome: FAO.

Chatfield, C. (1954). Food and Agriculture Organization Nutrition Study, no. 11, Rome: FAO.

Cole, A.H. (1976). Untersuchungen zum Energieumsatz bei normalgewichtigen und adiposen Personen als Beitrag zum Problem Ernährung und Leistung und als theoretischmethodische Voraussetzung entsprechender Untersuchungen unter tropischen Bedingungen. Inaugural Dissertation, Akademie der Wissenschaften der DDR, Berlin.

Cole, A. H., Karst, H., Ketz, H. A., Klingler-Mandig, H. \& Möhr, M. (1977). Deutsche Gesundheitwesen 32 , 1517-1522.

Cole, A. H. \& R. F. Ogungbe (1987). British Journal of Nutrition 57, 309-318.

Davidson, S., Passmore, R., Brock, J. F. \& Truswell, A. S. (1975). Human Nutrition and Dietetics, 6th edn, pp. 28-30. Edinburgh: Churchill Livingstone.

de Guzman, M. P. E. (1984). In Protein-Energy Requirement Studies in Developing Countries, United Nations University Food and Nutrition Bulletin, Suppl. 10, pp. 187-192. Tokyo: UNU.

Durnin, J. V. G. A., Blake, E. C. \& Brockway, J. M. (1957). British Journal of Nutrition 11, 85-94.

Durnin, J. V. G. A. \& Brockway, J. M. (1959), British Journal of Nutrition 13, 41-53.

Durnin, J. V. G. A. \& Passmore, R. (1967). Energy, Work and Leisure. London: Heinemann.

Ferro-Luzzi, A., Norgan, N. G. \& Durnin, J. V. G. A. (1975). American Journal of Clinical Nutrition 28, $1443-1453$

Food and Agriculture Organization (1950). First Committee on Calorie Requirements. FAO Nutritional Studies no. 5. Rome: FAO.

Food and Agriculture Organization (1957). Second Committee on Calorie Requirements, FAO Nutritional Studies no. 15. ROME: FAO.

Food and Agriculture Organization/World Health Organization (1973). Energy and Protein Requirements. Technical Report Series no. 522. Geneva: WHO.

Food and Agriculture Organization/World Health Organization/United Nations University (1985). Energy and Protein Requirements. Technical Report Series no. 724. Geneva: WHO.

Fox, R. H. (1953). Energy expenditure of Africans engaged in various rural activities. PhD Thesis, University of London.

Garry, R. C., Passmore, R., Warnock, G. M. \& Durnin, J. V. G. A. (1959). Medical Research Council Special Report Series no. 289. London: MRC.

Haenel, H. (1979). Energie und Nährstoffgehalt von Lebensmitteln: Lebensmitteltabellen. Berlin, DDR: Volkseigener Betrieb Verlag Volk und Gesundheit.

Klein, P. D., James, W. P. T., Wong, W., Irving, C. S., Murgatroyd, P. R., Cabrera, M., Dallosso, H. M., Lein, E. R. \& Nichols, B. L. (1984). Human Nutrition: Clinical Nutrition 38C, 95-106.

Leung, W. W., Pecot, R. K. \& Watt, B. K. (1952). Agriculture Handbook: United States Department of Agriculture no. 34. Washingdon DC: United States Department of Agriculture.

McCance, R. A., Hamad, E. B., Nasar, E. D., Widdowson, E. M., Southgate, D. A., Passmore, R., Shirling, D. \& Wilkinson, M. (1971). Philosophical Transactions of the Royal Society of London 259B, 533-565.

Müller, E. A. \& Franz, H. (1952). Arbeitsphysiologie 14, 499.

Nicholls, L. (1945). Tropical Nutrition, 2nd ed. London: Ballière, Tindall and Cox.

Nicol, B. M. (1949). British Journal of Nutrition 3, 25-43.

Nicol, B. M. (1956a). British Journal of Nutrition 10, 181-197.

Nicol, B. M. (1956 b). British Journal of Nutrition 10, 275--285.

Nicol, B. M. (1959). British Journal of Nutrition 13, 293-306.

Norgan, N. G., Ferro-Luzzi, A. \& Durnin, J. V. G. A. (1974). Philosophical Transactions of the Royal Society of London 268B, 209-348.

Philips, P. G. (1954). Journal of Tropical Medicine 57, 12.

Platt, B. S. (1945). Medical Research Council Special Report Series no. 253. London: MRC.

Rahaman, M. M. \& Durnin, J. V. G. A. (1964). Journal of Applied Physiology 19, 1188-1191. 
Schutz, Y., Lechtig, A. \& Bradfield, R. B. (1980). American Journal of Clinical Nutrition 33, 892-902.

Viteri, F. E., Torun, B., Galicia, J. C. \& Herrera, E. (1971). American Journal of Clinical Nutrition 24, $1418-1430$

Weir, J. B. D. (1949). Journal of Physiology 109, 1.

Zhi-Chien, H. O. (1984). In Protein-Energy Requirement Studies in Developing Countries, United Nations University Food and Nutrition Bulletin, Suppl. 10, pp. 193-200. Tokyo: UNU. 